Resumo de Tese

\title{
Educação permanente em saúde no Programa Saúde da Família em Montes Claros: intenções, realidades e possibilidades.
}

\section{Continuing health education in the Family Health Program in Montes Claros: intentions, realities and possibilities.}

Alcione Gonçalves Ribeiro Vieira

\section{Resumo}

O estudo versa sobre Educação Permanente em Saúde e consistiu em analisar a experiência de formação no trabalho de duas equipes do Programa Saúde da Família no município de Montes Claros, tendo como referência as diretrizes da Política Nacional de Educação Permanente em Saúde. A metodologia adotada foi a investigação qualitativa e os sujeitos da pesquisa foram os trabalhadores de saúde. $\mathrm{O}$ eixo norteador foram os processos de educação e de trabalho e nesses os processos participativos, os saberes e experiências relativas às práticas de saúde no cotidiano das unidades. O estudo apontou a existência da formação em serviço, integrando o processo educativo às práticas de saúde, mas sendo desenvolvida de forma incipiente e não sistematizada. Constatou, ainda, o desenvolvimento de treinamentos e capacitações para atualização dos trabalhadores, que se caracterizavam por utilizar metodologias tradicionais e concentrarse, em termos do planejamento, formulação dos temas e conteúdos, no nível central da Secretaria Municipal de Saúde, desvinculados das práticas concretas das Unidades de Saúde. O processo educativo direcionado à população caracterizavase pela prescrição de comportamentos, considerados tecnicamente mais corretos. Os resultados obtidos mostraram que a proposta de Educação Permanente não estava implantada em sua plenitude nas equipes em tela, embora estivessem presentes ações educativas que refletem suas diretrizes. Um dos desafios apontados foi a ampliação da participação de sujeitos sociais na viabilização e construção destas unidades como espaço de relações de trabalho e de formação.

Dissertação de Mestrado 2006 Universidade Estadual de Montes Claros

Desenvolvimento Social - Ciências Sociais Aplicadas.

\section{Disponivel para consulta em:}

http:/ / servicos.capes.gov.br/capesdw/resumo.html?idtese $=20061232014015002 \mathrm{P} 4$

Palavras-chave: Educação Permanente em Saúde; Processo Educativo; Processo.
Key Words: Continuing Education in

Health; Education Process; Process. 